\title{
HAEMOPHILIA AND RELATED CONDITIONS
}

\author{
By R. G. Macfarlane, M.D. \\ Clinical Pathologist, Radcliffe Infirmary; Radcliffe Lecturer in Haematology, University of Oxford
}

\section{Introduction}

Until recently haemophilia could be cited as an excellent example of a clearly defined clinical condition. Its symptomatology, inheritance and pathological findings were striking and characteristic, and diagnosis seldom presented any serious difficulties. But now the situation has changed; new methods of investigation have revealed the fact that the term 'haemophilia,' as usually applied, may cover more than one, perhaps several, distinct entities which differ from each other in the mechanism of their causation, and their response to specific treatment. These findings have, of course, necessitated a complete revision of ideas, and have thrown the existing system of terminology into confusion. There are, moreover, indications that further revisions are impending and it may be some years before another period of comparative stability in this field is reached. This article is at best an interim report on a rapidly changing situation, and it must be recognized that what are thought to be facts and valid conclusions now may soon be considered fallacious.

\section{Historical}

The evolution of the concept of haemophilia has followed a course which has many parallels in medical history; there are, for instance, striking similarities in the development of ideas on pernicious anaemia. At the beginning of the last century it became generally recognized that certain patients were liable to bleed uncontrollably from quite trivial injuries. Descriptions of individuals or of whole families affected in this way were published with increasing frequency, but for many years there was no uniform terminology, nor any clear ideas as to the possible causes of the abnormality. Many terms, such as 'haemorrhoea,' 'pernicious haemorrhage,' ' haemorrhaphilia' and 'idiosyncrasia haemorrhagica' were used to describe these cases. The name ' haemophilia' was apparı ntly introduced by Hopff in 1828 , but it did not become widely applied until some 20 or
30 yẹars later. Even then it was by no means restricted to the sort of cases that would be labelled h emophilia today; it was used to describe conditions now recognizable as purpura haemorrhagica, scurvy, telangiectasia and many cases of haemorrhage caused by some organic disease.

The modern concept of haemophilia as a clinical entity probably originated from the work of Nasse (1820), who pointed out among the heterogeneous descriptions of bleeders many instances of a hereditary condition, affecting only males and transmitted only by apparently normal females. Such a peculiar inheritance attracted considerable attention and the use of the term 'haemophilia ' became more an 1 more restricted to those cases in which a family history conforming to 'Nasse's law' could be obtained. The monumental survey of Bulloch and Fildes (I9II), covering the whole of the available literature, finally established the term ' haemophilia' in this sense.

Until the end of the rgth century the diagnosis of haemophilia rested entirely on clinical and genetic findings. The persistent liability to bleed occurring in a male from early infancy, the periodic swelling of the joints and evidence of a similar condition in brothers, maternal uncles or cousins provided the diagnostic criteria of that time. Any ideas on the cause of the condition were necessarily theoretical. It was usually supposed that the tissues or blood vessels were unduly fragile; though it was noted by Liston (1839) that the blood of a haemophilic patient coagulated slowly and incompletely, the haemostatic importance of efficient clotting was not widely appreciated. It was not until 1893 that Wright established that the coagulation time of the blood was characteristically prolonged in haemophilia, and not until igio was it shown by Addis that defective clotting is the only demonstrable cause of the haemorrhagic tendency.

Meanwhile, there had been a growth of interest in the mechanism of blood coagulation and it was natural that many who worked on this subject should try to determine the cause of the delayed 
clotting of haemophilic blood. The fact that this objective was unattained for more than 30 years was an indication that the normal process of coagulation was only partially understood. As each factor of the clotting mechanism was identified, its deficiency was thought to be the basic defect in haemophilia. In turn a deficiency of fibrinogen, calcium, prothrombin, platelet factor and thromboplastin was postulated, and refuted.

\section{The Clotting Defect in Haemophilia}

The first indications of the true nature of the defect in haemophilia came from the work of Addis (I9II). He showed that a small proportion of the globulin fraction of normal plasma when added to haemophilic blood caused it to clot within the normal time. Unfortunately he concluded that this effect was due to prothrombin and thus that a deficiency of prothrombin was the cause of haemophilia. When it was later shown that the prothrombin concentration of haemophilic blood was normal, Addis's work was discredited and forgotten. It was not until 1937 that Patek and Taylor again demonstrated the corrective effect of a normal plasma globulin fraction on haemophilic blood and suggested that this effect was due to an 'antihaemophilic factor' present in normal blood but lacking in haemophilia. From this work came the recognition of a clotting factor, hitherto ignored by the classical theory of coagulation, which became known as " antihaemophilic globulin.' It is found in the globulin fraction of the plasma associated with fibrinogen, and in fractions $\mathrm{I}, \mathrm{III}_{2}$ and $\mathrm{III}_{3}$ of Cohn (Minot and Taylor, 1947); it is consumed or inactivated during clotting and is not present in serum; it is not absorbed by $\mathrm{BaSO}_{4}$ or $\mathrm{Al}(\mathrm{OH})_{3}$. This recognition of the basic defect allowed the definition of haemophilia to be expanded to include a deficiency of antihaemophilic globulin as an essential feature.

Attempts were then made to determine the importance of this factor in the normal clotting mechanism. In 1947 both Quick and Brinkhous showed that it was concerned with the platelets, and after contact with a foreign surface, in the activation of prothrombin. Quick suggested that antihaemophilic factor was the precursor of thromboplastin being activated by platelets; he renamed it 'thromboplastinogen' and haemophilia ' hypothromboplastinogenaemia.' Brinkhous suggested that the platelets released thromboplastin after being lysed by the action of the antihaemophilic factor which he therefore named ' thrombocytolysin.' There was little experimental evidence available to favour either of these hypotheses.

Further information on the first stages of coagulation has been provided by the experiments of Dr. Rosemary Biggs and her colleagues (1953). It is now apparent that normal clotting is initiated by the generation within the blood of an extremely powerful, but labile, thromboplastin. This thromboplastin, when formed, is capable of clotting plasma in eight seconds or less, but the process of its formation, which is initiated by contact with a foreign surface, takes several minutes. It is this interval which constitutes the main part of the normal 'clotting time' of the blood. Several factors, including the platelets and antihaemophilic globulin, are concerned in the generation of thromboplastin, and the concentration of the latter directly affects the time at which thromboplastin first appears in the blood, and also the speed of its generation, once this begins. Thus when there is a deficiency of antihaemophilic factor the clotting time may be prolonged and, even when coagulation begins, fibrin formation is slow and incomplete. It appears that the intrinsic thromboplastin of the blood is of prime importance in physiological coagulation and it is likely that 'tissue thromboplastin,' once thought to be essential, is relatively unimportant. Haemophilic blood is coagulated in normal time by the addition of either normal or haemophilic tissue extracts (Brown, 1952), yet haemophilic patients notoriously suffer extensive bleeding into the tissues, indicating that tissue thromboplastins can have little effect in limiting the spread of extravascular blood by promoting coagulation.

\section{The Changing Definition of Haemophilia}

Clearer understanding of the cause of haemophilic haemorrhage led to changes in the criteria by which the condition was usually defined. It had become accepted, for instance, that a long clotting time was an essential diagnostic finding. How then should one classify cases in which the clinical and genetic manifestations resembled those of haemophilia but in which the coagulation time was almost or completely within normal limits? Merskey (195I) was able to show in such cases that, though the clotting time of the blood as ordinarily measured might be normal, the clotting efficiency as measured by the more sensitive prothrombin consumption test was abnormal. He demonstrated a deficiency of antihaemophilic factor in these patients, showing that their plasma was much less effective than normal in correcting the clotting defect of blood from a ' classical' haemophilic. Merskey classified these cases as 'mild haemophilia,' though in some instances the term 'mild' was more related to the prolongation of the clotting time than to the clinical disability, which might be very severe. It is clear, from this, that the simple clotting time 
of the blood is not a sensitive index of a deficiency of antihaemophilic globulin, or of the liability to bleed. An interesting point is that 'mild haemophilia' breeds true, short clotting times being found in all affected members of the different families examined.

Other developments were concerned with the genetics of haemophilia. Bulloch and Fildes (I9II) had maintained that the condition was not transmitted in any way by the affected male, that it did not occur in females, and that isolated cases, without family history, should not readily be accepted as instances of haemophilia. None of these restrictions would be applied now. It is known that the affected male passes the condition to his daughters, all of whom are potential transmitters capable of producing both normal and affected sons, and normal and carrier daughters. These observations are in concordance with the theory that haemophilia is inherited as a sex-linked recessive character, carried by a gene located on the $\mathrm{X}$ chromosome. Acceptance of this implies that a female heterozygous for haemophilia, a daughter of an affected male and a carrier female, should exhibit active haemophilia. Three such cases have been recorded within the past few years, in two instances (Merskey, 195I; Pinniger and Franks, I95I) affected females having been produced by cousin inter-marriage in haemophilic families, and in the third (Israels, Lempert and Gilbertson, 195I) because the daughter of a haemophilic was so proficient in nursing her father that she was regarded as an eminently suitable wife for a haemophilic.

Further confirmation of the occurrence of affected females has been provided by the breeding experiments of Brinkhous and Graham (1950), using haemophilic dogs. Concerning sporadic cases, it is now realized that haemophilia has a high mutation rate, and that from 20 to 30 per cent. of otherwise ' classical' cases may have no history of haemophilia in previous generations. Mutation may arise in the female, causing an apparently normal woman to produce one or more attected children, or it may occur in the male, in which case a haemophilic boy is the only affected member of the family. There is unfortunately no reliable method for detecting the carrier state in females (Merskey and Macfarlane, 195I). Their identitication would be of immense importance in reducing the incidence of haemophilia, but, despite many attempts, it has not yet proved practical.

\section{Acquired 'Haemophilia' and Christmas Disease}

With new methods available for studying defective coagulation, attention was naturally directed towards the conditions which lie on the boundaries of ' classical' haemophilia. A number of cases were discovered in which a deficiency of antihaemophilic globulin was apparently the cause of severe haemorrhagic symptoms, but which was acquired and not inherited. Joules and Macfarlane (1938) demonstrated such an acquired deficiency arising without obvious reason, in a middle-aged woman, and called the condition 'pseudo-haemophilia.' A number of observers have reported similar cases, but mainly in association with prignancy, and in some of these an anticoagulant has been found to be present in the blood, which has the effect of inhibiting or destroying the antihaemophilic factor, and which may be an antibody produced by some antigenic upset associated with pregnancy. Similar antibodies have been observed in the blood of haemophilics after transfusion or injection of antihaemophilic globulin (Biggs and Macfarlane, 1953).

It has thus been shown that conditions other than haemophilia may have a deficiency of antihaemophilic globulin; it has also been shown, more disturbingly, that in many cases which had been confidently diagnosed as haemophilia there was no such deficiency. The usual methods for the assay of antihaemophilic globulin are based upon the ability of the sample to correct the clotting defect of blood or plasma derived from a ' classical' haemophilic, the degree of correction being determined by the simple clotting time, or by the more sensitive prothrombin consumption test. It would not be expected that blood from one case of haemophilia would show any marked corrective effect when mixed with the blood of another. Yet Pavlovsky (1947), Koller et al. (1950), Aggeler et al. (1952), Schulman and Smith (1952) and Poole (1953) all reported that blood obtained from certain cases closely resembling haemophilia had the ability to correct the clotting defect of blood from other haemophilic cases. This suggests that at least two basically different clotting defects exist within the condition commonly known as haemophilia. Further information was provided by the observations of Biggs et al. (1952). These authors studied a group of seven cases clinically resembling haemophilia, the blood from which corrected the deficiency in blood from a number of cases of 'classical' haemophilia. Since mixing blood samples derived from these seven patients produced no mutual correction, it was considered that all were examples of the same clotting defect. Investigation by means of the newly devised thromboplastin generation test (Biggs and Douglas, 1953) revealed the fact that these patients were dencient in a clotting factor not previously recognized, and which was essential for blood thromboplastin 
formation. This factor was shown to be normally present in serum and readily adsorbed by $\mathrm{Al}(\mathrm{OH})_{3}$, thus being sharply differentiated from the antihaemophilic factor, which is not normally present in serum and is not adsorbed by $\mathrm{Al}(\mathrm{OH})_{3}$. Under the influence of the current practice of naming new red-cell antigens after patients, and of the close approach of December 25, the new factor was called 'Christmas factor' and the condition 'Christmas disease,' from the surname of the first patient investigated. It was shown that there was no deficiency of antihaemophilic globulin in Christmas disease, nor of Christmas factor in ' classical ' haemophilia, the two conditions appearing to be basically distinct.

Other conditions similar to, and possibly identical with, Christmas disease have been described. In the case studied by Aggeler et al. (1952) it was shown that there was a deficiency of a factor normally present in serum, and which was called 'P.T.C.' (plasma thromboplastin component). Two families containing in all 13 males affected by 'P.T.C.' deficiency have been investigated by Lewis and Ferguson (1953). It appears from the data published that P.T.C. and Christmas factor may be one and the same. Cramer et al. (1953) describe also two families of a haemorrhagic condition they have called 'Haemophilia B,' and have shown that the basic defect is probably a deficiency of Christmas factor. It is evident from personal communications that a number of other families previously reported as examples of haemophilia have now been found to be suffering from Christmas disease. It is too early to assess with any confidence the relative incidence of haemophilia and Christmas disease, but from figures so far available a rough estimate would suggest that the ratio is about ro to $I$.

Further complications may arise. Rosenthal et al. (1953) report three cases of haemorrhagic diathesis occurring in one family in which the clotting defect appears to be due to the deficiency of a new factor which is neither antihaemophilic globulin nor Christmas factor. They have tentatively called this hypothetical agent 'P.T.A.' (plasma thromboplastin antecedent). Koller(1953) also has evidence that points to the existence of yet another factor which he has called ' Factor ro,' antihaemophilic factor being called by him 'Factor 8' and Christmas factor 'Factor 9.' But time must elapse before the inter-relationship and even the existence of these factors is established.

\section{Deficiency of Factors 5 and 7}

In addition to haemophilia, Christmas disease and the more hypothetical P.T.A. and Factor ro deficiencies, there are haemophilia-like states produced by a lack of other factors which are con- cerned in thromboplastin generation. Both Factor 5 (pro-accelerin) and Factor 7 (pro-convertin) are required for the generation in the blood of the direct activator of prothrombin. The naturally occurring deficiency of either factor is rare. The first case of Factor 5 deficiency was described by Owren (1947) under the name ' parahaemophilia.' In Owren's patient a haemorrhagic condition had existed from early childhood, though there was no family history. Owren (1953) has also observed a further case, this patient's mother and sister being affected. Other cases are described by Frank et al. (1950), Koller et al. (1950), Stohlman et al. (1951), Cosgriff and Leifer (1952). Factor 7 deficiency as a congenital or hereditary condition has been described by Owren and Aas (195I) under the name ' hypoproconvertinaemia' and by Alexander et al. (I95I). Owren (1953) describes a large family with at least 12 members affected by Factor 7 deficiency, inherited apparently as a simple dominant.

Long-standing and severe deficiency of either Factors 5 or 7 , whether inherited or acquired, results in symptoms closely resembling those of haemophilia. Temporary Factor 7 deficiency is now deliberately produced by the administration of drugs of the dicoumarol group, the resulting clotting defect and lengthening of the "prothrombin time' being the aim of therapy designed to lessen the risk of thrombosis and embolism. In such cases, however, the deficiency should not become severe enough to promote bleeding.

\section{The Diagnosis of Haemophilia and its Related Conditions}

From a clinical point of view, the separation of haemophilia from its related conditions is important, because the basic defects are different, and any specific treatment must aim at replacing the factor which is actually deficient. Yet this separation cannot be made by clinical means, nor by the usual laboratory tests. The disorder common to all these.states is a faulty production of blood thromboplastin, and this defect, though it may be produced in different ways, will produce the same clinical effects. There will be the familiar picture of prolonged bleeding from injuries, of massive tissue haemorrhages and, probably, haemarthroses. There is some indication that patients with Christmas disease tend to be less severely affected than those with haemophilia, but this is too indefinite to be of diagnostic value in individual cases. Christmas disease, like haemophilia, is inherited as a sex-linked recessive character. That two such clinically similar conditions should share this rare type of inheritance is unlikely to be mere coincidence, and it is probable that the two factors involved, with perhaps others also concerned in 


\begin{tabular}{|c|c|c|c|c|c|}
\hline \multirow{2}{*}{ Condition } & \multirow{2}{*}{ Defect } & \multirow[t]{2}{*}{ Inheritance } & \multirow{2}{*}{$\begin{array}{l}\text { Pro- } \\
\text { thrombin } \\
\text { Time }\end{array}$} & \multicolumn{2}{|c|}{$\begin{array}{l}\text { Thromboplastin } \\
\text { Generation Test }\end{array}$} \\
\hline & & & & Plasma & Serum \\
\hline $\begin{array}{l}\text { Haemophilia } \\
\text { Christnas disease } \\
\text { 'Parahtemophilia' } \\
\text { 'Hypoproconvertinaemia', }\end{array}$ & $\begin{array}{l}\text { A.H.G. deficiency } \\
\text { Christmas factor de- } \\
\text { ficiency } \\
\text { Factor } 5 \text { deficiency } \\
\text { Factor } 7 \text { deficiency }\end{array}$ & $\begin{array}{l}\text { Sex-linked recessive } \\
\text { Sex-linked recessive } \\
\text { Non sex-linked } \\
\text { Non sex-linked }\end{array}$ & $\begin{array}{l}\text { Normal } \\
\text { Normal } \\
\text { Abnormal } \\
\text { Abnormal }\end{array}$ & $\begin{array}{l}\text { Abnormal } \\
\text { Normal } \\
\text { Abnormal } \\
\text { Normal }\end{array}$ & $\begin{array}{l}\text { Normal } \\
\text { Abnormal } \\
\text { Normal } \\
\text { Abnormal }\end{array}$ \\
\hline
\end{tabular}

The Differentiation of Hafmophilia and its Rfiated Conditions.

thromboplastin formation, have a genetic as well as a functional association for reasons not yet apparent. The practical point is that no differentiation between these conditions can be made from a study of the family historits. On the other hand, deficiency of Factors 5 or 7 , when hereditary, does not show a sex-linked inheritance.

The differential diagnosis between haemophilia and its related conditions therefore rests upon special pathological findings. In both haemophilia and Christmas disease the platelet count, bleeding time, tourniquet test and prothrombin time are usually normal, but the clotting time and prothrombin consumption tests are abnormal. The two conditions can be readily separated by the thromboplastin generation test. In this test is measured the rate of thromboplastin production in plasma treated with $\mathrm{Al}(\mathrm{OH})_{3}$ when mixed with serum and platelets; each component can be derived from normal (control) blood or from the blood of the patient under investigation. In haemophilia it is found that the plasma is abnormal in promoting thromboplastin generation, whereas in Christmas disease it is the serum which is abnormal.

The laboratory differentiation of Factors 5 or 7 deficiency from haemophilia and Christmas disease is provided by the fact that in the latter two conditions the 'prothrombin time' is normal, whereas in both Factors 5 and 7 deficiencies it is prolcnged. This is because both Factors 5 and 7 are required for the conversion to active thromboplastin of the Erain extract used in the prothrombin time test, which is not a complete thromboplastin. Factor 5 deficiency may be distinguished from Factor 7 deficiency by means of the thromboplastin generation test, since Factor 7 is normally present in serum and Factor 5 in plasma (see table).

\section{Treatment}

As regards the treatment of these conditions, there has been no major advance for the past 15 years. No consistently effective general treatment has yet been produced. It has long been recognized, however, that the transfusion of fresh normal blood often has beneficial effects in haemo- philia, reducing the clotting time and helping to control otherwise intractable haemorrhage. These effects are probably due to the antihaemophilic factor present in normal blood. But two points must be recognized if transfusions are to be useful. Antihaemophilic factor may be rapidly consumed, even in citrated blood, by pre-coagulation reactions following contact with glass. To be effective, therefore, the blood must be used as soon as possible, certainly not more than a few hours after collection. The second point is that probably much larger transfusions are required than was originally supposed. It has been found that an amount of blood which will reduce to normal the clotting time of a haemophilic patient's blood will have relatively little effect on the more sensitive prothrombin consumption, thrombin generation or thromboplastin generation tests. In 'mild' haemophilia, patients may bleed severely, while the clotting time is almost normal, but these sensitive tests always show a gross abnormality. It is probable, therefore, that the clotting time is a less reliable index of haemostatic efficiency than the latter tests, and therapy should aim at reducing all tests to normal, in cases of dangerous bleeding or before embarking on minor surgery. This may require the transfusion of relatively large amounts of normal blood, perhaps 5o per cent. of the blood volume, and even then the effect may only last a few hours. It is obvious, therefore, that major surgery should never be undertaken in haemophilia unless it provides the only chance of survival. Fresh blood transfusion will also tend to correct the defect in Christmas disease, and in Factors 5 and 7 deficiencies; information as to the amount required is incomplete. Factor 7 and Christmas factor, being much more stable than antihaemophilic factor and Factor 5, are probably active in stored blood for several days.

Many attempts have been made to treat haemophilia by injections of antihaemophilic factor which has been concentrated and purified in various ways. Specific therapy of this sort has many advantages and has been successful in some cases, but many disappointments have also occurred. Patients have failed to respond, and 
in some cases have apparently developed antibodies to the factor and suffered reactions. In any case, it is clear that, for such specific therapy to succeed, the diagnosis of haemophilia must be certain. A proportion of failures to respond to administration of antihaemophilic globulin may be due to the fact that the patients concerned lacked not antihaemophilic factor, but Christmas factor, or some other component of the thromboplastin-forming system. A re-examination of this aspect of the problem may have enlightening results.

Local treatment, though often useful, cannot be relied upon to promote and maintain haemostasis. In the case of external haemorrhage, it is most important to avoid making matters worse by drastic attempts to control the bleeding. Ligatures, sutures, and tight dressings are not only useless in these haemorrhagic conditions, they may be positively dangerous. They may lead to wide extravasation of the blood into the tissues which, in the region of the throat or mediastinum, may be disastrous. Local measures should therefore be restricted to haemostatic applications. Thrombin, which effectively coagulates the blood in all the haemophilia-like states, when combined with an absorbable dressing such as fibrin foam or oxidized cellulose and applied with light pressure, provides the best method for securing local haemostasis.

\section{BIBLIOGRAPHY}

ADDIS, T. (1910), 'Hereditary haemophilia. Deficiency in the coagulability of the blood, the only immediate cause of the condition,' Quart. F. med., 4, 14.

ADDIS, T. (I9II), 'The pathogenesis of hereditary haemophilia,' F. Path. Bact., $15,427$.

AGGELER, P. M., WHITE, S. G., GLENDENING, M. B., PAGE, E. W., LEAKE, T. B., and BATES, G. (1952), 'Flasma thromboplastin component (P.T.C.) deficiency. A 79, 692 .

ALEXANDER, B., GOLDSTEIN, R., LANDWEHR, G., and COOK, C. D. (1951), 'Congenital S.P.C.A. defíciency; a hitherto unrecognized coagulation defect with haemorrhages rectified by serum and serum fractions,' $¥$. clin. Invest., 30, 596.

BIGGS, R., DOUGLAS, A. S., MACFARLANE, R. G., DACIE, J. V., PITNEY, W. R., MERSKEY, C., and O'BRIEN, J. R. (19j2), "Christmas disease. A condition previously mistaken for haemophilia,' Brit. med. $\mathcal{F}$., ii, 1378 .

BIGGS, R., and MACFARLANE, R. G. (1953), 'Human Blood Coagulation and its Disorders,' Blackwell's Scientific Publications, Oxford.

BIGGS, R., and DOUGLAS, A. S. (1953), 'The thromboplastin generation test,' Y. clin. Path., 6, 23.

BIGGS, R., DOUGLAS, A. S., and MACFARLANE, R. G; (1953)," The formation of thromboplastin in human blood, f. Physiol., 119, 89, and in Press.

BRINKHOUS, K. M. (1947), 'Clotting defect in hemophilia. Deficiency in a plasma factor required for platelet utilization, Proc. soc. exp. Biol. N.Y., 66, 117.

BRINKHOUS, K. M., and GRAHAM, J. B. (1950), 'Hemophilia in the female dog,' Science, $\mathbf{1 1}, 723$.
BROWN, A. (1952), Personal communication.

BULLOCH, W., and FILDES, P. (1911), ' Haemophilia. 'Treasury of Human Inheritance,' Parts 5 and 6, Dulau \& Co., London.

COSGRIFF, S. W., and LEIFER, E. (I952), ' Factor V deficiency in haemorrhagic diathesis (parahaemophilia), $\mathcal{F}$. Amer. Med. Ass., 148, 462.

CRAMER, R. VON, MATTER, M., and LOELIGER, A. (1953), 'Die hämophilie B,' Helv. Paediatr. Acta., 8, 185.

FRANK, E., BILHAN, N. VoN, and EKREN, H. (1950), 'Die Parahämophilie (Owren). Eine neue Form der hemorrhagischen diathese,' Acta Haemat., 3, 70.

HOPFF, F. (I828), 'Ueber die Haemophilie oder die erbliche Anlage zu tödtlichen Blutungen,' Inaug. Diss. Wurzburg, quoted by Bulloch and Fildes.

ISRAELS, M. C. G., LEMPERT, H., and GILBERTSON, P. (195 I), 'Haemophilia in the female,' Lancet, $i, 1375$.

JOULES, $H$., and MACFARLANE, R. G. (r938), 'Pseudohaemophilia in a woman, Ibid., i, 715 .

KOLLER, F., KRUSI, G., and LUCHSINGER, P. (1950), 'Ueber eine besondere Form hämorrhagischer Diathese, Schrveiz. med. Wschr., 80, I I0I.

KOLLER, F., GASSER, C., KRUSI, G., and MURALT, G. DB (1950), 'Purpura fulminans nach Scharlach mit Factor V mangel und Antithrombin-überschlus,' Acta Haemat., 4, 33.

KOLLER, F. (1953), 'Communication to the 4th Congress of the International Society of Haematology,' Amsterdam, September.

LEWIS, J. H., and FERGUSON, J. H. (1953), 'Hemorrhagic diathesis due to P.T.C. (plasma thromboplastin component) deficiency,' Proc. soc. exp. Biol. Med., 82, 445.

LISTON, R. (1839), ' Haemorrhagic idiosyncrasy,' Lancet, ii, 137.

MERSKEY, C. (195I) 'Haemophilia associated with a normal coagulation time,' Brit. med. $\mathcal{F}$., $1,906$.

MERSKEY, C. (195I), "The occurrence of haemophilia in the human female,' Quart. F. Med., 20, 299.

MERSKEY, C., and MACFARLANE, R. G. (1951), ' The female carrier of haemophilia. A clinical and laboratory study,' Lancet, i, 487 .

MINOT, G. R., and TAYLOR, F. H. L. (1947), 'Hemophilia; The clinical use of antihemophilic globulin,' Ann. Int. Med., 26, 363 .

NASSE (1820), 'Von einer erblichen Neigung zu tödtlichen Blutungen,' Arch. med. Erfahr. Horn., 1, 385.

OWREN, P. A. (1947), ' Parahaemophilia. Haemorrhagic diathesis due to absence of a previously unknown clotting factor,' Lancet, $1,446$.

OWREN, P. A., and AAS, K. (195I), "The control of dicumarol therapy and the quantitative determination of prothrombin and proconvertin,' Scand. F. clin. Lab. Invest., 3, 201.

OWREN, P. A. (1953), ' Prothrombin and accessory factors,' Am. F. Med., 14, 201.

PATEK, A. J., and TAYLOR, F. H. L. (1937), 'Hemophilia. II.-Some properties of a substance obtained from normal human plasma effective in accelerating the coagulation of hemophilic blood,' $\mathcal{F}$. clin. Invest., 16, 113 .

PAVLOVSKY, A. (1947), 'Contribution to the pathogenesis of hemophilia,' Blood, 2, 185 .

PINNIGER, J. L., and FRANKS, R. B. (1951), 'Haemophilia in the female, Lancet, ii, 82.

POOLE, J. C. F. (1953), 'A haemorrhagic state resembling haemophilia,' Lancet, i, 122.

QUICK, A. J. (1947), 'Studies on the enigma of the hemostatic dysfunction of hemophilia,' Amer. Y. med. Sci., 214, 272.

ROSENTHAL, R. L., DRESKIN, O. H., and ROSENTHAL, N. (r953), 'New hemophilia-like disease caused by deficiency of a third plasma thromboplastin factor,' Proc. soc. exp. Biol. Med., 82, 171 .

SCHULMAN, I., and SMITH, C. H. (1952), 'Hemorrhagic diathesis in an infant due to deficiency of a previously undescribed clotting factor,' Blood, 7, 794.

STOHLMAN, F., HARRINGTON, W. J., and MOLONEY, W. C. (1951)," ' Parahaemophilia (Owren's disease). Report of a case of a woman with studies on other members of her family,' F. lab. clin. Med., 38, 842 .

WRIGHT, A. E. (1893), ' On a method of determining the condition of blood coagulability for clinical and experimental purposes, and on the effect of the administration of calcium salts in haemophilia and actual or threatened haemorrhage," Brit. med. Y., il, 22,3. 